УДК 378.016: [811.161.2'243'42:908(477)]

DOI: $10.24144 / 2524-0609.2021 .48 .284-288$

\author{
Nazarevych Lesia \\ Candidate of Philological Sciences, Ph.D., Associate Professor \\ Department of Ukrainian and Foreign Languages \\ Ternopil Ivan Puluj National Technical University, Ternopil, Ukraine \\ lesia.te@gmail.com \\ ORCID ID: http://orcid.org/0000-0002-0566-9200 \\ Denysiuk Nadia \\ Candidate of Philological Sciences, Ph.D., Associate Professor \\ Department of Ukrainian and Foreign Languages \\ Ternopil Ivan Puluj National Technical University, Ternopil, Ukraine \\ denysiuknadia@gmail.com \\ ORCID ID: http://orcid.org/0000-0001-8197-2183 \\ Kotovska Tamila \\ Candidate of Philological Sciences, Ph.D., Associate Professor \\ Department of Foreign Languages, Information and Communication Technologies \\ West Ukrainian National University, Ternopil, Ukraine \\ tamilakotovska@gmail.com \\ ORCID ID: http://orcid.org/0000-0002-1032-5912
}

\title{
SPECIFIC FEATURES OF STUDYING CROSS-CULTURAL TEXTS IN CLASSES OF UKRAINIAN AS A FOREIGN LANGUAGE
}

\begin{abstract}
The urgency of the problem is to study the Ukrainian language in a foreign language environment based on cross-cultural texts that help students adapt to the country of residence and be acquainted with its realities. The objective of the study is to emphasize the need for selecting texts and didactic materials with consideration of feasibility and practical application of a particular information and the development of communicative competence; to prove the expediency of diversification of tasks and examples as one of the best ways of explaining foreign communicators this or that phenomenon, depending on a situation; to share the experience of teaching the Ukrainian language among non-communicators. A detailed analysis of current research and publications is conducted. The focus is on communicative, personal-oriented, cultural, and level methods, on the importance of visualization, pre-text and post-text exercises, various questions, descriptive interpretation of rarely used vocabulary, extended vocabulary, etc. Research methods used: descriptive, comparative, empirical approaches. The main task in the process of learning a foreign language is highlighted, namely an understanding the concept in context: there are certain meanings in a foreign language for which there are no literal equivalents in the native language, for example, phraseological units. Formulation of post-text questions, paraphrasing the text parts, additional interpretation, comparative analysis - this is an opportunity to encourage students to talk, activate critical thinking, and help them understand Ukraine, Ukrainian realities and Ukrainians. However, the texts should be updated in accordance with the communicative situation, emphasizing the phrases necessary in everyday life. The teacher's task is to develop students as welleducated personalities, so it is advisable to ask a variety of questions during the discussion, which help not only assess students and find out how well they understand the material, but also promote the development of speech. Thus, the teacher's challenge is to choose carefully the content of texts in order to adapt the foreign students to the language environment, which would promote Ukraine in the world, contribute to the formation of linguistic knowledge about Ukraine.
\end{abstract}

Key words: Ukrainian as a foreign language; communicative approach; linguistic texts; adaptation; teaching methods.

Introduction. Adaptation of foreign students in Ukraine partly depends on the level of proficiency in the Ukrainian language, psychological and physical possibility of immersion in the Ukrainian-speaking space, and language training, which is based on processing cross-cultural texts. The ability to establish communicative connections in the group is of great importance, as well as the motivation and desire to learn, skills of memorizing and modifying the acquired linguistic knowledge.

Analysis of recent research and publications. Since the middle of the twentieth century, the linguistic aspect has been of interest to scientists from around the world (K.Apel, F.Buslaev, T.Voloshinova, V. Von Humboldt, J.Grimm, J.Gerder, B.Kassen, K.Klakhon, O.Potebnya, E.Stewart, E.Hall, G.Steinthal, K.Jaspers, etc.). At the present stage, linguistic issues are covered by Ukrainian scholars, in particular O.Antoniv, V.Gorodetska, O.Gorda, V.Vladimirova, V.Kononenko, T.Leshchenko, D.Mazuryk, N.Malyuga, S.Pilishek,
M.Redkva, N.Sarnovska, O.Trumko, H.Shvets, O. Shevchenko and others. Due to the interest in the Ukrainian language as a foreign language, every year more and more methodological and scientific works appear, in which cross-cultural texts act as a basis for the theoretical and practical approach to intercultural communication. The monograph by H.Shvets «Theory and practice of teaching Ukrainian to foreign students of humanities» is a significant contribution to the development of Ukrainian as a foreign language (UFL) [1]. In this work, a focus is made on coverage, analysis, and theoretical justification of cross-cultural and local lore approaches. The methodological base is annually replenished with works of Ukrainian linguists, in particular H.Shvets «Meet! Kyiv», «Journey to Ukraine», «Apple», «Step» and others. A novelty is the textbook «The Key to Ukraine. Cities and people» [2]. This is a common two-volume work by Ukrainian linguists at the International Institute of Education, Culture and Relations with Diaspora at Lviv Polytechnic National University. Stories about modern 
events in Ukraine («Donetsk», «Cyborg Remembrance Day», «Savur Grave») are touching and encouraging sympathy and nostalgia. The advantage of these texts is in shifting the emphasis on heroism, victory, thirst for victory, the struggle for freedom in the homeland. In addition, letters and instructions from Vasyl Stus, an excerpt from the speech of I.Kalynets «Three stories about 300 soldiers», an excerpt from V.Shklyar's novel «Black Sun», and photos with cyborgs are designed to broadcast the truth about Ukraine, debunk many myths from «Soviet» times; to form the proper thoughts, preferences, inner character; to stimulate self-education. Such material is important, interesting, necessary not only for foreigners, but also for students who receive education in their native language, so that they do not make mistakes at the level of state formation.

Noteworthy is the textbook on the Ukrainian language for foreign students by H.Shvets «Meet: Kyiv», which presents local lore historical-reference and popular science texts. The author, following the principle of consistency, gradually «leads» the foreigner from simpler to more complex material, distinguishing typical lexical and grammatical constructions presented in the texts. She also builds grammatical tasks according to the stylistic features of the texts [3].

At Ternopil Ivan Puluj National Technical University (TNTU), foreign students are studied according to the textbook «Ukrainian language for foreigners. Level B1-B2» by L.Nazarevych and N.Havdyda [4]. Through the prism of texts about famous figures, sights of Ukraine, legends, symbols, the Ukrainian language is positioned as a socio-cultural phenomenon in the system of national values. In addition to texts about every day, educational, business, economic, political, scientific, and technical life, the practising teachers prove the expediency of studying songs. This consideration is discussed more thoroughly in the authors' work «Song creativity a component of the methodology of teaching Ukrainian as a foreign language» [5].

The objective of the article is to share the experience gained by the Department of Ukrainian and Foreign Languages of TNTU in the field of teaching Ukrainian as a foreign language, to highlight issues related to working with local lore texts in the study of this discipline. Thus, Ukrainian is positioned as a sociocultural phenomenon in the system of national values, the tool of developing communicative competence of speakers, and the method of adaptation to a foreign language country. In addition, the emphasis should be made on the importance of working with pre-text and post-text exercises, semanticization and visualization of vocabulary, selection of didactic material, based on communicative needs and the level of language proficiency of students. Methods of teaching Ukrainian as a foreign language are the subject of research.

The methodological basis is a hermeneutic approach, the essence of which is to consider broad textual and non-textual factors, and diverse contexts. Research methods: bibliographic one is applied to identify, select and systematize scientific and educational literature; descriptive - to describe cross-cultural texts and tasks; analytical - to systematize and structure educational material into small components for the introduction of communicative and reproductive exercises during the classes of Ukrainian as a foreign language; inductive - for the embodiment of practical examples at the pre-theoretical level; empirical - to share the experience of teaching at TNTU; cultural-historical - to consider the phenomena proposed for study in broader contexts; contextual - to consider each phenomenon in the context of history, psy- chology, and cultural traditions.

Problem statement. The issue of studying Ukrainian as a foreign language by foreign students who receive higher education in Ukraine is relevant for teachers-linguists in terms of teaching methods. For non-communicators, language is not only an academic discipline, the vocabulary and grammatical constructions, but also a means of obtaining the necessary information in an unfamiliar environment, a way of adapting to the country of residence. Hanna Shvets remarks: «We consider a text local lore providing it describes the spatial, temporal, social and cultural features of a certain territory. ... Educational scientific texts about Ukraine, which form the basis of a textbook on country studies and are also used in the practical course of UFL, are called cross-cultural ones» $[1, \mathrm{p} .259]$. Such texts contribute to the immersion of intercultural groups in language and culture at the verbal and nonverbal levels. Based on the above, crosscultural texts are the main array for working in the classroom, which is necessary for the promotion of tangible and intangible national heritage of Ukraine.

To acquaint foreigners with Ukrainian history and prominent figures through the prism of learning the Ukrainian language is a difficult way as the peculiarities of psychology and the interests of those for whom the material is intended should be taken into account. In addition, students who came from other countries have a completely different language picture. That is why we consider the necessity to work with texts that would bring up the issues of life, environment, cultural leisure, recreation, education, science and technology, sports, health, nutrition, ecology, social and political life, traditions, customs and holidays, stereotypical thinking of Ukrainians, economy, etc. Communicative skills and abilities to each of the levels (A1-B2) should be built on all types of speech activity: listening, reading, speaking, and writing. This approach is primarily based on standardized requirements for the levels of proficiency in Ukrainian as a foreign language [6], and in addition, is designed to talk to non-communicators, to broaden their horizons.

The main goal during the lessons is to improve the student's speaking skills, which is formed on reading competence. At the initial level of language acquisition, you should not dive into the complex pages of the historical past or build an ideal Ukraine with all its archetypes, but those who study Ukrainian as a foreign language at the level of B1-B2, C1-C2, should be provided with the texts and tasks that would open more facts about Ukraine. Humorous stories, news, press articles, short videos about traveling in Ukraine, cuisine, life, music, traditions, phrases, recipes act as appropriate illustrative material that unobtrusively introduces foreigners to our realities.

An indispensable component of every lesson in Ukrainian as a foreign language, as well as any other foreign language, is the work with pre-text and post-text exercises. In TNTU, in classes on Ukrainian as a foreign language, in addition to educational texts, we practice the study of folk and modern songs. Linguistic and stylistic elaboration of lyrics deepens the aesthetic and cognitive reception of cultural phenomena. Our observations are confirmed by the words of $H$. Shvets. According to the researcher, songs contribute to «effective practice of pronunciation (articulation, accentology, orthoepic, intonation) and auditory skills, mastering lexical and grammatical norms of language, development of productive skills, formation of linguistic competence» $[1$, p.324]. We offer students to perform interactive exercises on the platforms Wizer.me (https://wizer.me/) and Learningapps (https://learningapps.org). Here you can- 
not just listen and remember, for example, the songs of the Christmas cycle («Mykolay Bearded», «Mykolay», «Dzen'-dzelen'», «New joy has become», «Oh, how grey is a cuckoo», «Shchedryk», but also train pronunciation, consolidate knowledge of morphology and syntax, memorize language clichés.

Let us dwell in more detail on «Shchedryk» by Mykola Leontovych. Applying a linguistic and cultural approach in the classroom allows foreigners to immerse themselves in the atmosphere of Ukrainian Christmas traditions. We propose to start classes with pre-text vocabulary (the first star, the Star of Bethlehem, Christmas Eve, kutia, Christmas star, carolers, Christmas carols, Christmas tree, didukh, manger, etiquette formulas Christ is born! Praise him! etc.), which is accompanied by visualization and comments. After pre-text work, audio and visual content, we offer texts about the traditions of celebrating Christmas, the history of «Shchedryk» by Mykola Leontovych, the song «Shchedryk» performed by different singers, statements, grammar exercises, and questions of varying difficulty, models and sentence patterns, affectionate forms of nouns, illustrations by contemporary artists. It is worth emphasizing the importance of comments to cross-cultural texts, because it is the comment that removes the difficulties of linguistic nature at the pre-text stage, complements or helps adjust the knowledge of foreign students [1, p.393].

For example, the comment "Singing Christmas carols is an old New Year's custom. During the performance of songs, a group of young girls and boys praises people, wishing them health and prosperity. The people thank them and give money or gifts for Christmas» is not complete, but it provides all necessary information for an adequate understanding of Ukrainian traditions, simplifies the perception of texts on relevant topics. Linguists emphasize that the commentary should not overload the reader with information [1, p.385].

Formulation of post-text questions, paraphrasing of parts of the text, additional interpretation, comparative analysis - this is an opportunity to encourage students to talk, activate critical thinking, help them understand Ukraine, Ukrainian realities and Ukrainians. However, the texts should be updated in accordance with the communicative situation, emphasizing the phrases necessary in everyday life. Thus, the Turkish journalist $\mathrm{Yu}-$ nus Erdoğdu remarks: «It is better to present not only grammatical constructions, but stable expressions ... It is impossible to teach a foreigner to speak, understand and write in Ukrainian if the emphasis is only on grammar. Each language possesses characteristic phrases; they are also present in Ukrainian» [7]. In the process of learning a foreign language, the main task is to understand the concept in context: in a foreign language, there are certain meanings for which there are no literal equivalents in the native language, for example, phraseological units. When we intend to explain this or that phenomenon to foreign communicators, we give different examples depending on the situation. For example, we explain a heavy downpour in Ukraine «It pours like from a bucket» (word-based translation (WBT)), but in English we translate this idiom «It's raining cats and dogs»; the well-known phrase «Make an elephant from a fly» (WBT) is translated as «A storm in a tea cup». Here, a word-based translation of English expressions into Ukrainian is inappropriate, even absurd, because no one says, "Cats and dogs are falling in the rain from the sky»). Therefore, we should look for a counterpart in a foreign language that would accurately convey the essence of the phenomenon. Not every word in one language has an exact equivalent in another. Thus, not all concepts that are expressed through the words of one language exactly coincide with the concepts that are expressed in words of other languages.

Appropriate use of idioms helps foreigners demonstrate knowledge of the language at the level of the native speaker and makes it possible to understand the idiomsmarkers of the Ukrainian language. For example, blackbrow girl; the language will lead to Kyiv; mosquito will not grind it's nose; the eyes are afraid but the hands do; who ate sorrel, and who had soreness of the mouth; no one looks at the teeth of a donated horse (WBT). In this case, the statement of Artur Schopenhauer is indisputable «If one has properly grasped the spirit of a foreign language, one has also taken a large step toward understanding the nation that speaks that language, as the style is related to the mind of the individual, so the language is related to the mind of the nation. A complete mastery of another language has taken place when one is capable of translating not books but oneself into the other language, so that without losing one's own individuality one can immediately communicate in that language; and thereby please foreigners as well as one's countrymen in the same manner» [8, p.34]. Therefore, based on the above, the texts should be arranged properly, as well-chosen materials help not only adapt to the country where foreigners live, but also become a part of it.

The teacher's task is to encourage students to talk, so it is advisable to ask different types of questions during the discussion. More details about open, closed, focusing, leading, evaluative and problematic issues are discussed in the work of L.Nazarevych [9]. In fact, the questions help not only evaluate the students and find out how well they understand the material, but also promote the speech development.

Communicative exercises, which are designed to paraphrase word combinations, write sentences from suggested words, ask all possible questions to sentences, complete sentences, replace narrative sentences with interrogative ones, retell a fragment about a historical monument, give a title, determine the main idea of the text, write plan, reproduce utterances, promote the development of speech skills of foreign students. Reproductive exercises, which help build utterances based on familiar grammatical material, should not be overlooked. That is why, listening exercises are so important when learning a language (the country studies texts we work with at TNTU are voiced and posted on the SoundCloud platform). Rapid saying should also be considered at all stages of language acquisition, as they are an excellent tool for training phonetics.

The presented material allows drawing the following conclusions: the teacher's task is to choose carefully the content for the adaptation of a foreign student to the language environment; to apply methods that would be subject to didactic purposes; to structure tasks; to select interesting unobtrusive historical and cultural material for reading and discussion; to obey the principle of sequence and continuity; to connect new information with already known material and to explain unfamiliar words; to give examples; to resort to pre-text commenting, etc. At the present stage of the development of Ukrainian as a foreign language, there is a need for high-quality multigenre texts that would promote Ukraine in the world and contribute to the formation of linguistic knowledge about Ukraine. Prospects for further research: the search for new ways of consistent communicative organization of the educational process in classes on Ukrainian as a foreign language, taking into account cultural and historical experience, national features, and the linguistic picture of the world of non-communicators. 


\section{Список використаної літератури}

1. Швець Г.Д. Теорія і практика навчання української мови іноземних студентів гуманітарних спеціальностей: монографія. Київ : Фенікс, 2019. 529 с.

2. Ключ до України: міста і люди: підручник з української мови як іноземної (Рівні В2-С1) / І.Ключковська та ін. Ч.2. Львів: Колір ПРО, 2020. 296 с.

3. Швець Г. Знайомтеся: Київ: навч. посіб. з української мови для студентів-іноземців. К.: Видавець Федоров О.М., 2011. $240 \mathrm{c}$.

4. Назаревич Л.Т., Гавдида Н.І. Українська мова для іноземців. Практикум (Рівні В1-В2). Тернопіль: ФОП Паляниця В. A., 2017. $212 \mathrm{c}$

5. Назаревич Л., Денисюк Н. Пісенна творчість - компонент методики навчання української мови як іноземної // Актуальні проблеми лінгводидактики в сучасному освітньому середовищі: матеріали Всеукраїнської наук.-практ. інтернет-конф. Тернопіль: Вектор, 2020. С.95-98

6. Антонів О., Синчак О., Бойко Г. Стандартизовані вимоги: рівні володіння українською мовою як іноземною А1-С2. Зразки сертифікаційних завдань: посіб. К.: Фірма «ІНКОС», 2020. 186 с.

7. Ердогду Ю. Чому я не зміг вивчити української. URL: https://detector.media/infospace/article/142578/2018-11-14-chomuya-ne-zmig-vivchiti-ukrainskoi/ (дата звернення: 01. 03. 2021).

8. Artur Schopenhauer. On Language and Words / Theories of Translation. An Anthology of Essays from Dryden to Derrida / edited by R.Schulte and J.Biguenet. Chicago: The University of Chicago Press, 1992. p.34.

9. Назаревич Л.Т. Запитання на заняттях української мови як іноземної - шлях до розвитку зв'язного мовлення // Українська мова у світі: збірник матеріалів VI Міжнар. наук.-практ. конф., м.Львів, 25 червня; 6 листопада 2020 р. Львів: ТзОВ «Галицька видавнича спілка», 2020. С.108-112.

10.Кассен Б. Більше однієї мови / пер. з фр. С.Желдак. Київ: ДУХ І ЛІТЕРА, 2016. 64 с.

\section{References}

1. Shvets, H. (2019). Teoriya i praktyka navchannya ukrayins'koyi movy inozemnykh studentiv humanitarnykh spetsial'nostey [Theory and practice of teaching the Ukrainian language to foreign students of humanities]. Feniks. [in Ukrainian].

2. Kliuchkovska, I., Horda, O., Trumko, O., Martynyshyn, N., Temnyk, H., \& Rusnak, O. (2020). Klyuch do Ukrayiny: mista $i$ liudy : pidruchnyk z ukrayins'koyi movy yak inozemnoyi (Rivni V2-S1) [The Key to Ukraine: Cities and People: A Textbook on Ukrainian as a Foreign Language (Levels B2-C1)]. Part 2. Kolir PRO. [in Ukrainian].

3. Shvets, H. (2021). Znayomtesya: Kyyiv: navchal'nyy posibnyk z ukrayins'koyi movy dlya studentiv-inozemtsiv [Meet: Kyiv: a textbook on the Ukrainian language for foreign students]. Vydavets Fedorov O. M. [in Ukrainian].

4. Nazarevych, L.T., \& Havdyda, N.I. (2017). Ukrayins'ka mova dlya inozemtsiv. Praktykum (Rivni V1-V2) [Ukrainian for foreigners]. Palyanytsya. [in Ukrainian].

5. Nazarevych, L., \& Denysiuk, N. (2020). Pisenna tvorchist' - komponent metodyky navchannya ukrayins'koyi movy yak inozemnoyi [Song creativity is a component of the methodology of teaching Ukrainian as a foreign language] Actual problems of language didactics in the modern educational environment: materials of the All-Ukrainian scientific-practical Internet conference (pp.95-98). Vektor. [in Ukrainian].

6. Antoniv, O., Synchak, O., \& Boyko, H. (2020). Standartyzovani vymohy: rivni volodinnya ukrayins'koyu movoyu yak inozemnoyu A1-S2. Zrazky sertyfikatsiynykh zavdan' [Standardized requirements: levels of proficiency in Ukrainian as a foreign language A1-C2. Samples of certification tasks]. Firma «INKOS». [in Ukrainian].

7. Erdoğdu, Y. (2020). Chomu ya ne zmih vyvchyty ukrayins'koyi [Why I could not learn Ukrainian] URL: https://detector.media/ infospace/article/142578/2018-11-14-chomu-ya-ne-zmig-vivchiti-ukrainskoi/. [in Ukrainian]

8. Schopenhauer, A. (1992). On Language and Words. Theories of Translation. An Anthology of Essays from Dryden to Derrida. The University of Chicago Press. [in English]

9. Nazarevych, L. (2020). Zapytannya na zanyattyakh ukrayins'koyi movy yak inozemnoyi - shlyakh do rozvytku zv"yaznoho movlennya. [Questions in Ukrainian as a foreign language are a way to develop coherent speech]. Ukrainian language in the world: collection of materials of the VI International scientific-practical conference (pp.108-112). Galician Publishing Union LTD [in Ukrainian]

10.Kassen, B. (2016). Bil'she odniyeyi movy [More than one language]. DUKH I LITERA. [in Ukrainian]

Стаття надійшла до редакції 24.03.2021 p. Стаття прийнята до друку 29.03.2021 р.

Назаревич Леся Тарасівна

кандидат філологічних наук

доцент кафедри української та іноземних мов

Тернопільський національний технічний університет імені Івана Пулюя м.Тернопіль, Україна

Денисюк Надія Романівна

кандидат філологічних наук

доцент кафедри української та іноземних мов

Тернопільський національний технічний університет імені Івана Пулюя м.Тернопіль, Україна

\section{Котовська Таміла Іванівна}

кандидат філологічних наук

доцент кафедри іноземних мов та інформаційно-комунікаційних технологій Західноукраїнський національний університет

м.Тернопіль, Україна

\section{СПЕЦИФІКА ВИВЧЕННЯ КРАЇНОЗНАВЧИХ ТЕКСТІВ НА ЗАНЯТТЯХ УКРАЇНСЬКОЇ МОВИ ЯК IHOЗEMHOÏ}

Анотація. Статтю присвячено актуальній проблемі: вивченню країнознавчих текстів на заняттях української мови як іноземної. У розвідці акцентовано на тому, що країнознавчі тексти допомагають 
міжкультурним групам адаптуватися до країни проживання та ознайомитися з їі реаліями. Мета публікації - проаналізувати країнознавчий матеріал, а також привернути увагу науково-педагогічної спільноти до необхідності підбирати тексти і дидактичні матеріали з урахуванням доцільності та практичного застосування країнознавчої інформації та розвитку комунікативної компетенції; довести доречність урізноманітнення завдань та прикладів як одного з кращих способів пояснити інокомунікантам специфіку використання типових мовних шаблонів, фразеологізмів залежно від ситуації; поділитися досвідом викладання української мови в середовищі іноземців. Зосереджено увагу на комунікативному, особисто-орієнтованому, культурознавчому, рівневому методах, важливості візуалізації дотекстових і післятекстових вправ, різнотипних запитань, описового тлумачення рідковживаної лексики, розширеного вокабуляру. Викладені в статті ідеї проілюстровано прикладами, взятими 3 досвіду викладання української мови як іноземної в Тернопільському національному технічному університеті імені Івана Пулюя. Методи дослідження: описовий, порівняльний, емпіричний. Виокремлено головне завдання - під час вивчення іноземної мови сприяти розумінню концепції в контексті, адже в чужій мові $є$ певні сенси, для яких у рідній мові нема дослівних відповідників (подано низку фразеологізмів, проаналізовано тексти про традиції та свята). Зосереджено увагу на доцільності ставити післятекстові запитання під час обговорення конкретної теми, оскільки запитання допомагають не лише оцінити студентів і з'ясувати, наскільки добре вони зрозуміли матеріал, а й сприяють розвитку їхнього мовлення. Крім того, простежено роль перефразування частин тексту, додаткового тлумачення лексем як способу «розговорити» студентів, активізувати критичне мислення, допомогти їм зрозуміти Україну, українські реалії та українців. Доведено, що тексти необхідно актуалізувати відповідно до комунікативної ситуації, акцентуючи на фразах, без яких не обійтися в побуті.

Ключові слова: українська мова як іноземна; комунікативний підхід; лінгвістичні тексти; адаптація; методи навчання. 